\title{
UPDATE OF THE PROFESSIONAL HABITUS FROM THE NURSES AT THE NATIONAL CANCER INSTITUTE (1980-1990) ${ }^{1}$
}

\author{
Maria Cristina Frères de Souza², Maria Angélica de Almeida Peres³, Gizele da Conceição Soares Martins ${ }^{4}$, \\ Antonio José de Almeida Filho
}

\footnotetext{
${ }^{1}$ Excerpt from the dissertation - The National Cancer Institute as a locus for the recycling and national recognition of the nurses' scientific capital in oncology (1980-1990), presented to the Doctoral Program at Anna Nery School of Nursing (EEAN) at Universidade Federal do Rio de Janeiro (UFRJ), in 2012.

${ }^{2}$ Ph.D. in Nursing. Nurse, Permanent Education, National Cancer Institute - Hospital do Câncer I. Rio de Janeiro, Rio de Janeiro, Brazil. E-mail: crisfreres@terra.com.br

${ }^{3}$ Ph.D. in Nursing History. Adjunct Professor, Fundamental Nursing Department, EEAN/UFRJ. Rio de Janeiro, Rio de Janeiro, Brazil. E-mail:aguaonda@uol.com.br

${ }^{4}$ Ph.D. candidate in Nursing. Faculty member, Nursing Program, UFRJ. Rio de Janeiro, Rio de Janeiro, Brazil. E-mail: gizelemartins16@hotmail.com

${ }_{5}^{5}$ Ph.D. in Nursing. Associate Professor, Fundamental Nursing Department at EEAN/UFRJ. Rio de Janeiro, Rio de Janeiro, Brazil. Email: ajafilhos@gmail.com
}

\begin{abstract}
Social historical study, whose goals are: to characterize the practice areas of nurses from the National Cancer Institute, where there was a need to incorporate new knowledge in oncology and discuss the symbolic gains for nurses. The primary sources were oral and written documents, analyzed according to Pierre Bourdieu's concepts of habitus and scientific capital. It was evident that, in the 1980s, the position of the Institute in the field of cancer care in Brazil, made the nurses acquire new knowledge in the areas of cancer surgery, clinical oncology and bone marrow transplantation. The nursing competences and procedures were reorganized and new patient care routines were structured. It is concluded that the strategies to occupy this space were developed through the sharing of scientific knowledge, with visibility of the scientific capital in the field of oncology and highly specialized care, getting national recognition.
\end{abstract}

DESCRIPTORS: Nursing. History of nursing. Oncologic nursing. Professional practice.

\section{ATUALIZAÇÃO DO HABITUS PROFISSIONAL DOS ENFERMEIROS DO INSTITUTO NACIONAL DE CÂNCER (1980-1990)}

RESUMO: Estudo histórico-social, com objetivos de caracterizar as áreas de atuação dos enfermeiros do Instituto Nacional de Câncer, onde houve a necessidade de incorporar novos conhecimentos em oncologia, e de discutir os ganhos simbólicos para os enfermeiros. As fontes primárias foram documentos escritos e orais, analisados segundo os conceitos de habitus e capital científico de Pierre Bourdieu. Evidenciou-se que, na década de 1980, a posição do Instituto Nacional de Câncer, no campo da assistência ao câncer no Brasil, fez com que os enfermeiros incorporassem novos conhecimentos nas áreas de cirurgia oncológica, oncologia clínica e transplante de medula ossea. As competências e procedimentos de enfermagem foram reorganizados e novas rotinas de atendimento ao paciente foram estruturadas. Conclui-se que as estratégias para ocupação desse espaço se desenvolveram através do compartilhamento de conhecimento científico, com visibilidade do capital científico no campo da oncologia e assistência altamente especializada, obtendo reconhecimento nacional. DESCRITORES: Enfermagem. História da enfermagem. Enfermagem oncológica. Prática profissional.

\section{ATUALIZACIÓN DEL HABITUS PROFESIONAL DE LOS ENFERMEROS DEL INSTITUTO NACIONAL DE CÂNCER (1980-1990)}

RESUMEN: Estudio histórico y social, que objetivó caracterizar las áreas de actuación de los enfermeros de Instituto Nacional del Cáncer, donde hubo la necesidad de incorporar nuevos conocimientos en oncología y discutir las ganancias simbólicas para los enfermeros. Las fuentes primarias fueron documentos escritos y orales, analizados según los conceptos de habitus y capital científico de Pierre Bourdieu. Se evidenció que en la que década de 1980, la posición de Instituto en el campo de la asistencia al cáncer en Brasil, ha contribuido para que los enfermeros incorporasen nuevos conocimientos en las áreas de cirugía oncológica, oncología clínica y trasplante de Medula Ósea. Las competencias y procedimientos de enfermería fueron reorganizados y nuevas rutinas de atendimiento al paciente fueron estructuradas. Se concluye que las estrategias para la ocupación de este espacio se desarrollaron a través del compartimiento del conocimiento científico, con visibilidad de capital científico en el campo de la Oncología yAsistencia altamente especializada, obteniendo reconocimiento nacional.

DESCRIPTORES: Enfermería. Historia de la enfermería. Enfermería oncológica. Práctica profesional. 


\section{INTRODUCTION}

At the start of the 1980's, despite the technological advances and the incorporation of new cancer diagnosis and treatment resources, the mortality coefficient of the disease remained practically unaltered, representing the second cause of death in Brazil. ${ }^{1}$ Due to the maintenance of these epidemiological indicators since the 1970's, the Instituto Nacional do Câncer (INCA), a fundamental entity for cancer control in Brazil, was chosen in 1980 to set up a co-management process, that is, of managerial and administrative co-participation among the Ministry of Health, the Ministry of Social Security and Social Services and the INCA itself, which started to receive financial resources for management, research, teaching and care. ${ }^{1}$

The co-management was aimed at rationalizing the use of the social security resources through the integration among the different ministries dedicated to health services, besides the valuation of the public health institutions in the framework of the proposed health reforms. This initiative responded to the new guidelines and strategies for improvement in public health service delivery in Brazil. ${ }^{2}$

In that context, the premise for cancer treatment, like any other pathology, was aimed at the discovery of effective procedures with the most limited side effects. The investment in innovation and technological development, involving the production of drugs with less potential toxicity and conservative surgical techniques would also require investments in the qualification of human resources in health.

The INCA, with the changes the co-management entailed in the 1980's, experienced the incorporation of new professionals and technicalscientific cooperation agreements with Brazilian universities and international research institutes, which contributed to enhance the research at the institution. In addition, new treatment protocols were created and new technologies were purchased. This was a fruitful scenario for the insertion of nursing in view of the new challenges imposed, in line with the determinations of the co-management proposal. ${ }^{3}$

The nurses hired by the INCA at the start of the 1980's, who worked at different hospital sectors, faced many challenges based on the restructuring of care, driven by the changes the comanagement required, which determined the need to gain specific knowledge on the employment of new chemotherapeutic drugs and symptom management; immediate and late effects of oncology treatment; new support technologies. ${ }^{3}$
In that context, the challenge the INCA nurses were confronted with was expressed in the need for professional qualification, in view of the growing demand for knowledge about the pathological processes of cancer and their respective specific care, with a specialized care method. In that sense, the objectives in this study are to characterize the activity areas of the INCA in the 1980's, with the need to incorporate new knowledge in oncology and to discuss the symbolic gains deriving from those nurses' incorporation of this knowledge.

This study is justified because it represents an advance on the knowledge produced about the theme, as it evidences the historical role of cancer nursing at the INCA in the reorganization of specialized care to cancer patients in Brazil.

\section{METHOD}

A historical-social study was undertaken of the 1980's, when the co-management process was developed at the INCA. The primary written sources used were: articles, books, reports, commemorative books and information bulletins from the National Campaign against Cancer (CNCC), available in the historical documents filed at the INCA.

The primary oral sources were the testimonies of seven nurses, whose inclusion criteria were qualitative aspects, such as: having occupied leading functions in the organizational and technical structure of the INCA during the study period; having worked in teaching, having participated effectively in the education processes and institutional committees; having participated in the elaboration of care protocols at the chemotherapy and radiotherapy sectors and in their dissemination.

Concerning the treatment of the recorded testimonies, the sound files were organized and catalogued to permit the consultation and use in the treatment of the interviews. They were transcribed and checked for reliability. To guarantee the trustworthiness of the transcribed material, it was presented to the interviewees for validation of the text. The mean duration of the interviews was 80 minutes.

The interviews, held between March 2010 and March 2011, were supported by a script with open questions, permitting discussions about the theme under analysis, without losing the question out of sight. The script included questions about the operation of professional training, research and patient care, based on the co-management process; the strategies to acknowledge and consolidate the specialized nursing knowledge at the INCA and in Brazil; and the difficulties and facilities in the 
implantation of the strategies related to the incorporation of knowledge about oncology. The script also considered the timetable of the events in the course of the research period that were relevant for the study problem. The interviewees were identified by the letter $\mathrm{D}$, followed by a sequential Arabic numeral.

The secondary sources derived from Brazilian and nursing history books, Brazilian nursing journals, dissertations, theses and studies on cancer nursing; and books and dissertations on the social, education and health policies in the field of Brazilian oncology. Also, Brazilian congress annals and journals were consulted that were produced in the 1980's and addressed cancer nursing and/ or oncology.

As the historical method recommends, the study included the three essential phases: data survey, critical analyses of these data and conclusions. Thus, after the selection and classification phase of the documentary sources, the quality and relevance of the information these sources contained were determined for the proposed historiographic work. This source validation process is called external criticism and internal criticism. ${ }^{4}$ In this process, the written and oral documents, as primary sources, were examined in detail, comparing them to the secondary sources; next, they were grouped in chronological order and according to the theme they addressed.

Then, the data were organized and analyzed in the light of the historical-social method. The set of political and social facts was also considered for the interpretation of the historical data, which permitted the historical presentation based on the selected documents. As mentioned, reliable data were achieved through the triangulation of the documentary sources. The analysis revealed the following themes: incorporation of specialized knowledge in cancer surgery; incorporation of specialized knowledge in clinical oncology and incorporation of specialized knowledge in bone marrow transplantation (SKBM).

The theoretical concepts of scientific capital and habitus, by the French sociologist Pierre Bourdieu, ${ }^{5}$ supported the study. The concept of capital, borrowed from economics, plays a central role in Bourdieu's thinking. With regard to the scientific capital, this can take two forms, with different laws of accumulation: pure scientific capital is mainly gained through the contributions to the progress of science, while the institutional scientific capital, used in this study, is essentially acquired through specific strategies, through the participation in examination boards, meetings, commissions, scientific events, among others. ${ }^{5}$
Hence, the concept of scientific capital guided the understanding that its accumulation demanded great personal investment from the INCA nurses, as any accumulation of capital presupposes assimilation, which takes time the investor should personally invest. ${ }^{6}$ Being personal, capital acquisition is work the subject performs on himself, that is, a property that becomes part of the person, a habitus. That is so because the habitus is an incorporated disposition that functions as a principle that generates distinct and distinctive practices, which the subjects' actions reflect and which update the marks of their social position and the structural distinctions that define them, as the habitus not only internalizes the external, but also externalizes the internal. ${ }^{7}$

Approval for the research was obtained from the INCA Research Ethics Committee under protocol number 16/10, on February $22^{\text {nd }} 2010$, in compliance with the ethical-legal recommendations the National Health Council proposed through Resolution 196/96. All interviews were held after the signing of the Free and Informed Consent Form.

\section{RESULTS}

The primary written sources and the testimonies of seven nurses who performed leading functions in the INCA structure permitted the construction of three categories, related to the incorporation of specialized knowledge, as follows.

\section{Incorporation of specialized knowledge in cancer surgery}

At the INCA, in the 1980's, in the co-management context, there were various surgical clinics, depending on the specificity of the surgical approach and treatment of the different tumor types. Each clinic had its team of surgeons and number of beds, distributed across nursing wards in several wings. ${ }^{8}$

Concerning the transformations inherent in the surgical innovations in cancer treatment and their implications for specialized nursing care, especially for the need to establish patient care routines, the following report states:

[...] we did the dressing in the morning, after the patient's bath, and before leaving. We wrote down the patients with wound necrosis and who needed to be assessed by the surgeon. We started to look for space with doctor Sérgio [oncologist Sérgio Allan] so as not to depend on the doctor on his team for this request. Then we started to ask the surgeon to see the breast with necrosis tissue, which perhaps needed debridement. We 
looked for space in that situation, also because there were lots of people, full of energy (D1).

At the Head and Neck Surgery Clinic, where surgeries like laryngectomies were done, one of the aspects considered for the nurses' activities was the urgent need to accumulate knowledge about oncology, independently of the experiences the nursing professionals had accumulated.

The paper published in January 1985, in the bulletin "Câncer Notícias", entitled "Atuação de Enfermagem na Clínica Cirúrgica de Cabeça e Pescoço" (Nursing Activities at the Head and Neck Surgery Clinic), written by nurse Tanan Moreno, head of nursing at that clinic at that time, observed that these professionals should not act "in a forced or persuaded manner" at that sector, but "out of free and spontaneous will". 9:6

Nursing directed care at the particularities of each oncologic surgery clinic. The pre and postoperative care presented countless peculiarities, according to the surgical intervention and characteristics of each patient; one of the aspects to be considered was the observation of the inclusion into adjuvant chemotherapy and/or radiotherapy protocols before the surgery, a primordial factor for care planning. ${ }^{10}$

\section{Incorporation of specialized knowledge into clinical oncology}

In the care context of the INCA, the Clinical Oncology Section, responsible for the chemotherapeutic drug treatment and clinical support in case of complications, showed a production of 2,309 external consults in the third term of 1981, increasing to 3,438 in the same period of 1982 , which represented an increase by $49 \%$. A similar phenomenon is observed in the analysis of the chemotherapy treatment, which reached the same percentage increase in December 1982, indicating an expansion in the demand for chemotherapy nursing care. ${ }^{10}$ The manipulation and administration of the drugs and specific nursing care at the INCA, used in treatment protocols, determined the incorporation of technical-scientific knowledge on chemotherapy administration. The testimonies below reveal strategies to incorporate this knowledge:

[...] the care started when chemotherapy was administered to the patient, if he was having some reaction $(\mathrm{D} 2)$.

[...] so I learned chemotherapy from the nurses who were already at the sector. It was about the correct dose, the correct patient, do it correctly and do not let it extravasate (D3).
Nursing took part in the restructuring of clinical oncology, updating its professional habitus, constructing and reformulating nursing care proposals and thus gaining recognition from the medical team and other professionals, according to the testimonies:

[...] after some time there, we innovated lots of things. We started to create rules, which would turn into protocols later [...]. I remember that we started drafting. I we were going to do CDDP [Cisplatin], MTX [Methotrexate], so we started to set up a protocol for the patients. We innovated a lot there (D1).

[...] some doctors, noticing the need for our work to grow, invested, opened doors and took nursing together. That happened a lot. Within the chemotherapy itself, in clinical oncology. We got great support, a lot of support (D4).

Therefore, the nurses started to incorporate the nursing knowledge in the field of clinical oncology, conquering space and postures in view of their peers:

[...] through the study, through dialogue with the physician, we built it. Then we started to adopt a posture in there that gave the power to solve (D2).

As a result of the establishment of comanagement, one of the areas that significantly developed was radiotherapy at the INCA, showing an increase in procedures by $76.9 \%$ (between 1979 and 1981), through the reorganization of human resources, equipment and administrative procedures. This development was driven by the Project Brazil-Canada, which aimed for scientific exchange with the Canadian institutions in order to implement care activities in advanced technology in the field of radiotherapy. ${ }^{1}$

The nurses who acted in this field participated in the dissemination of this knowledge through the scientific sections, organized by the INCA Study Center in 1984, as published in its information bulletin. Therefore, they acted as authorized and acknowledged spokespersons to point out their specialized knowledge. ${ }^{10}$

It is clear that the nursing at INCA invested in an interdisciplinary posture, resting on permanent and updated studies, as well as on the partnership with the entire care team, resulting in qualified activities that result in recognition for cancer nursing.

Incorporation of specialized knowledge at the Bone Marrow Transplantation Center (SKBM)

In 1980, the creation of the Bone Marrow Transplantation Center (SKBM) was authorized 
at the INCA. ${ }^{11}$ As a result of the inauguration of the SKBM, yet another important activity area for nursing was constituted in oncology, with important investments in the nurses who would be allocated to this sector, furthering the incorporation of specific knowledge for a therapeutic approach in the field of bone marrow transplantation. ${ }^{12}$ Therefore, these nurses would serve as the authorized spokespersons of nursing care for cancer patients who were submitted to this kind of transplantation.

Thus, the nurses who would be allocated to this sector had to participate in a course and, at the end, were submitted to an assessment, with written and oral tests, administered by the course coordinators to indicate the professionals that were considered apt for hiring. One of the interviewees emphasized the importance of training for nursing at the INCA:

the training course for the SKBM nurses and the recruitment period in 1983 took about three months [...]. This training course was the prelude, granted the INCA nurses a new view, leading to the creation of the Nursing Residency (D5).

The training staff of that course consisted of physicians, nurses, a biochemist, nutritionist and psychologists. The presenting nurses accumulated functions in the coordination of the course and related areas, which were part of the activity area, all of whom were very well-positioned in that social space, in function of the accumulated scientific capital they incorporated. ${ }^{10}$

The specialized content in the undergraduate programs was taught in a reduced manner, which demanded stricter and more comprehensive training for these professionals:

[...] it took us one year moving around the hospital, learning to take care of these cancer patients [...]. We also did seminars. Eliana [nurse Eliana Teixeira Barreto] did lots of meetings, gave themes for research and presentation to the colleagues. So as to truly gain oncologic knowledge, because at that time the schools did not even mention oncology [...]. That is, the whole base was really in here [...] (D6).

The initial staff distribution proposal at the SKBM was to use the INCA nurses' experience. Because of their low adherence, however, a selection process was promoted with the participation of external professionals. With this intent, in 1983, the Recruitment, Selection and in-Service Education Commission was officially established in 1983 through Service Order 19, in January 1983, signed by INCA director Ary Frauzino Pereira and by the Regional CNCC Coordinator Nildo Eimar de Aguiar. ${ }^{12}$ This Commission included four nurses from the institution who were experienced in oncology nursing and in care delivery to cancer patients: Claudia Tereza Pinheiro (CNCC nurse and hospitalization service supervisor), Eliana Maria Teixeira Barreto (CNCC nurse and Intensive Care Unit supervisor), Heliacy Lima Barros Bastos (Ministry of Health nurse and radiotherapy supervisor) and Maria Lucia Monteiro da Silva (CNCC nurse and Coordinator of the School of Auxiliary Nurses of the Hospital dos Servidores do Estado/INAMPS/INCA). ${ }^{13}$

To enhance the technical-scientific preparation, with a view to working in such as specialized and challenging area, nurses Eliana Teixeira Barreto and Claudia Tereza Pinheiro organized a Nursing Manual with procedural standards and routines, which served as a source of consultation and an element to guide these professionals' conduct:

[...] so we created the SKBM Nursing Manual [...]. We used a method similar to what was done at the INCA later, with the agent, the action. We did everything structure, the step by step of each routine. How the chemotherapy preparation would be, about the bed bath. It resulted in a huge manual. We did all of the routines so that, when the staff arrived, they would already have some support for how it would work (D7).

In the case of the SKBM nurses, the cultural capital was specific, resulting in a symbolic gain, represented by the better technical positioning of cancer nursing, and in prestige before their peers. And thus, once again, the INCA nurses were able to disseminate the authorized discourse in a new professional activity area. This condition took the form of power and prestige for nursing at this institution.

\section{DISCUSSION}

In the multidisciplinary cancer treatment, surgery is the eldest therapeutic modality. It was the first treatment that significantly altered the course of the disease and, until today, it is one of the main therapeutic methods. It is estimated that about $60 \%$ of all cancer patients need surgery for their treatment. ${ }^{14}$

The nursing practice at the surgical clinics demanded skills and knowledge inherent in the physiopathology of the tumors, the surgical approach and its complications, surgical wound care, care with devices like tubes, drains, stomas and prostheses, with rehabilitation and mainly the approach coherent with the physiological alterations and their reflexes in the body image resulting from the mutilations. In most cases, the tumor was in an advanced stage. ${ }^{9}$ 
The patients from the Head and Neck Surgery Clinic, in the cancer context, did not only have their self-image altered. In addition, the possible associations of the treatment forms and how long the patient is submitted to it can entail severe reactions. ${ }^{12}$ Therefore, besides the impact of the disease diagnosis, the patients suffer out of fear of losing control, of disfiguration and the consequent rejection by the family and society. ${ }^{15-16}$

Another aspect that demands tolerance and special skills from professionals who deal with cancer patients refers to the limits they are confronted with in verbal communication, which requires concentration skills to understand and establish appropriate communication links and attend to their needs. In the case of these patients, non-verbal communication, using all the senses for perception, decoding of messages, observation of the personal space and bodily expression may be the most effective form of interaction. ${ }^{17}$

The nurses stay close to the patients and families at difficult times, clarifying or delivering immediate care. Thus, they have to deal with the suffering, anguish and fear that can emerge in different situations involving this care. ${ }^{16}$

The delivery of this care demands not only knowledge on the disease itself from the nurses, but also skills to deal with other people's feelings and with their own emotions towards cancer patients. ${ }^{18-19}$

Besides the surgery, another pillar of cancer treatment is anti-neoplastic chemotherapy, representing the systemic treatment of malign tumors. It can be administered in isolation but is more frequently associated with the surgery and/or radiotherapy. ${ }^{15}$

In the 1980's, in the field of clinical oncology at the INCA, the adjuvant treatment was consolidated, whose function is to complement the intervention after surgery and/or radiotherapy, in the initial phases of the disease, through the reduction in the number of cancer cells, with greater sensitivity to chemotherapy. Thus, the cure of patients with metastases was conquered exclusively through chemotherapy. ${ }^{20}$

As the chemotherapy is a systemic treatment, whose anti-neoplastic agents are toxic, and therefore subject to collateral effects, this enhances the importance of the nurses' participation in the administration and monitoring of the side effects of the chemotherapy. ${ }^{17}$

In this period, the pharmaceutical industry strongly invested in the chemotherapeutic agents, which equally demanded technological development. In this respect, the following can be mentioned: the laminar flux hood to dilute these drugs, with a view to protecting the professional during the manipulation; the indwelling central venous catheters and the infusion pumps for the administration of vesicant and other drugs. ${ }^{20}$

In accordance with the above, as strategies to occupy a space in this area, the nurses used the sharing of scientific knowledge and the space granted by the other agents, in order to gain visibility of their scientific capital in the field of oncology and, as a counterpart, to offer highly specialized care, contributing to the institutional recognition. In this analysis perspective, Bourdieu's contribution is needed, when he highlights that the agents create the space, and the space only exists through the agents and the objective relations among them. The volume of their capital determines the structure of the field proportionately to their weight, which depends on the weight of all other agents, that is, of the entire space. ${ }^{5}$

The creation of the SKBM ${ }^{11}$ was a huge investment, which permitted new guidelines for the cancer treatment through the implementation of a national referral unit. Initially, allogeneic (between different persons) and autologous (from a person to him/herself) bone marrow transplantations were done; attending to patients from the state of Rio de Janeiro and other Brazilian regions. The creation of this social space was yet another landmark in the updating of the INCA nurses' professional habitus. ${ }^{10}$

In accordance with the interpretation deriving from Bourdieu, the nurses accumulated legitimate competency and, therefore, were recognized as authorized and trustworthy spokespersons. In this line of understanding, the use of language depends on the speaker's social position; that is, on the institutionalized recognition and the belief received from a certain group. The discourses are signs to be understood, deciphered, assessed, appreciated, and also signs of authorities to be believed and obeyed. ${ }^{5}$

IN addition, it should be recognized that, when they entered the INCA, the nurses were confronted with a new knowledge area. Studies undertaken in the 1980's to identify the existence of cancerology teaching at the nursing schools revealed the lack of oncology contents from the undergraduate course programs. ${ }^{21}$

The lack of this scientific capital in nursing education did not grant the competency required from care delivery to cancer patients, mainly to work in such a specialized and therefore complex sector like the SKBM, nor technical-scientific preparation to assume important functions in the 
cancer control programs. The nurses' entry in the field of oncology and the articulation of the knowledge the nurses incorporated in this social space granted the professionals opportunities to build a specific capital, that is, characteristic of the bone marrow transplantation units.

Thus, the nurses needed to search reformulations in their forms of thinking and acting, in view of what is demanded from them in their care practice as well as in teaching, in view of the scientific and technological innovations of each age. ${ }^{21}$ This contributed to the problem-solving ability of health care, as the effective equating of the health problems and care the patients presented is essential for the humanization of care. ${ }^{22}$ Mainly with regard to cancer patients and everything involved in this condition, as it is important for the nurses, as professionals present in the processes that involve radiotherapy and chemotherapy, to contribute towards the optimization of treatment and the improvement of the patients' quality of life. ${ }^{15}$

As a result of the restructuring in activity areas, into clinical oncology, surgical oncology, radiotherapy and bone marrow transplantation, the nurses' participation in certain institutional spaces granted them recognition, acquired through their attitudes towards the care processes, as a result of the mastery of scientific knowledge and cooperation with the multidisciplinary team. ${ }^{23}$

While the Institute started an expansion process in the care, teaching and research areas, it drove the development and consolidation of the scientific capital in cancer nursing at the INCA.

\section{FINAL CONSIDERATIONS}

As the research demonstrates, when they entered the INCA, the nurses were confronted with a challenging field of new knowledge and needed to overcome the lack of knowledge in oncology, due to gaps in their education, whose curriculum did not provide the competency needed for cancer patient care, nor to assume important functions in cancer control programs.

In the 1980's, the group of INCA nurses constructed their knowledge through the accumulation of experiences deriving from daily professional work in each specific area of oncology, of the theoretical study about the specialty and the exchanges deriving from interdisciplinary activities. All of this was based on stimuli for the development of cancer research and care, a philosophy that is preserved at the institution until today. The updating of the professional habitus became one of the main challenges, as the knowledge about the physiopathological processes of cancer demanded specific care from the professionals, through a complex and specialized care method.

As they gained new knowledge, the nurses conquered space and recognition in the multiprofessional team. The scientific and technological advances for diagnosis and medical treatment purposes in oncology required an equally qualified Nursing Service, capable of applying the full arsenal of available knowledge.

This was a moment of conquering space for the nurses, as holders of specific capital in cancer nursing. The strategies to occupy that space were developed through scientific knowledge sharing, which furthered the visibility of the scientific capital in oncology and, at the same time, highly specialized care, articulated with the proposal to enhance the care quality at the institution.

The results of this study reveal the need to develop other research with a view to a better understanding of the strategies the INCA nurses used to define cancer prevention and control policies in Brazil. In addition, the INCA was the first institution that qualified nurses specialized in cancer care, through the creation of the first nursing residency program in this area.

\section{REFERENCES}

1. Teixeira LA, coordenador. De doença desconhecida a problema de saúde pública: o INCA e o controle do câncer no Brasil. Rio de Janeiro (RJ): Ministério da Saúde; 2007.

2. Ministério da Saúde (BR). Instituto Nacional de Câncer. Instituto Nacional de Câncer - 50 anos. Rio de Janeiro (RJ): INCA; 1989.

3. Ministério da Saúde (BR). Instituto Nacional de Câncer. Campanha Nacional de Combate ao Câncer: plano de trabalho de 1989. Rio de Janeiro (RJ): INCA; 1989 b.

4. Padilha MICS, Borenstein MS. O método de pesquisa histórica na enfermagem. Texto Contexto Enferm [online]. 2005 Out-Dez [acesso 05 Ago 2012]; 14(4):575-84. Disponível em: http://www.scielo. br/pdf/tce/v14n4/a15v14n4.pdf

5. Bourdieu P. Os usos sociais da ciência: por uma sociologia clínica do campo científico. São Paulo (SP): UNESP; 2004.

6. Bourdieu P. Escritos de Educação. $2^{\mathrm{a}}$ ed. Rio de Janeiro (RJ): Editora Vozes; 1998.

7. Bourdieu P. O poder simbólico. Rio de Janeiro (RJ): Bertrand; 2001.

8. Barreto EMT. Levantamento administrativo de estrutura e serviços hospitalares. [relatório técnico]. Rio de Janeiro (RJ): Universidade do Estado do Rio de Janeiro; 1982. 
9. Ministério da Saúde (BR). Instituto Nacional de Câncer. Atuação de enfermagem na clínica cirúrgica de cabeça e pescoço [boletim interno/informativo]. Rio de Janeiro (RJ): INCA; 1985.

10. Ministério da Saúde (BR). Instituto Nacional de Câncer. Centro de Estudos e Ensino Amadeu Fialho. [boletim interno/informativo]. Rio de Janeiro (RJ): INCA; 1983.

11. Resolução CIPLAN n. 12 de 4 de agosto de 1982. Autoriza a criação do Centro de Transplante de Medula Óssea (CEMO) do INCA. Diário Oficial da República Federativa do Brasil, Brasília (DF), 04 ago. 1982. Seção 1:1

12. Barreto EMT, Lourenço LHSC, Almeida Filho AJ. O Centro Nacional de Transplante de medula óssea no Instituto Nacional de Câncer: os primeiros desafios da implantação. Esc Anna Nery [online]. 2003 Dez [acesso 13 Ago 2012]; 7(3):406-12. Disponível em: http://www.redalyc.org/pdf/1277/127718223012. pdf

13. Ministério da Saúde (BR). Instituto Nacional de Câncer. Centro de Estudos e Ensino Amadeu Fialho. [boletim interno/informativo]. Rio de Janeiro (RJ): INCA; 1983.

14. Ministério da Saúde (BR). Instituto Nacional de Câncer. Ações de enfermagem para o controle do câncer: uma proposta de integração ensino-serviço. $3^{\text {a }}$ Ed. Rio de Janeiro (RJ): INCA; 2004.

15. Santos RCS, Dias RS, Giordani AJ, Segreto RA, Segreto HRC. Mucosite em pacientes portadores de câncer de cabeça e pescoço submetidos à radioquimioterapia. Rev Esc Enferm USP [online]. 2011 [acesso 11 Ago 2012]; 45(6):1338-44. Disponível em: http://www.scielo.br/pdf/reeusp/v45n6/ v45n6a09.pdf

16. Sousa DM, Soares EO, Costa KMS, Pacífico ALC, Parente ACM. A vivência da enfermeira no processo de morte e morrer dos pacientes oncológicos. Texto
Contexto Enferm [online]. 2009 Jan-Mar [acesso 11 Ago 2012]; 18(1):41-7. Disponível em: http:/ / www. scielo.br/pdf/tce/v18n1/v18n1a05.pdf

17. Figueiredo NMA, Tonini T, Machado WCA, Moreira MC, Leite JL. Enfermagem Oncológica: conceitos e práticas. São Caetano do Sul (SP): Yendis; 2009.

18. Oliveira AM, Pozer MZ, Silva TA, Parreira BDM, Silva SR. Ações extencionistas voltadas para a prevenção e o tratamento do câncer ginecológico e de mama: relato de experiência. Rev Esc Enferm USP [online]. 2012 [acesso 13 Ago 2012]; 46(1):240-5. Disponível em: http://www.scielo.br/pdf/reeusp/ v46n1/v46n1a32.pdf

19. Hoga LAK. A dimensão subjetiva do profissional na humanização da assistência à saúde: uma reflexão. Rev Esc Enferm USP [online]. 2004 [acesso 22 Set 2012]; 38(1):13-20. Disponível em: http://www. scielo.br/pdf/reeusp/v38n1/02.pdf

20. Ministério da Saúde (BR). Instituto Nacional de Câncer. Histórias da oncologia clínica do Instituto Nacional de Câncer. Rio de Janeiro (RJ): INCA; 2008.

21. Rodrigues C, Queiroz J. A situação atual do ensino de enfermagem oncológica nos cursos de graduação em enfermagem no Brasil. Rev Paul Enferm. 1988 Jan-Mar; 8(1):23-5.

22. Moreira MC, Carvalho V, Silva MM, Sanhudo NF, Filgueira MB. Produção de conhecimento na enfermagem em oncologia: contribuição da Escola de Enfermagem Anna Nery. Esc Anna Nery [online]. 2010 Jul [acesso 22 Set 2012]; 14(3):575-84. Disponível em: http://www.scielo.br/pdf/ean/ v14n3/v14n3a20.pdf

23. Santana CJM, Lopes GT. O cuidado especializado do egresso da residência em enfermagem do Instituto Nacional de Câncer - INCA. Esc Anna Nery [online]. 2007 Set [acesso 13 Ago 2012]; 11(3):417-22. Disponível em: http://www.scielo.br/pdf/ean/ v11n3/v11n3a04.pdf 